\title{
Innovation and Practice of the Mode of Management and Service in Colleges-Taking Beihang University as an Example
}

\author{
Jing-Xia Shi \\ Administration office, Beihang University, Beijing, China \\ shijingxia@buaa.edu.cn
}

Keywords: Management service mode, Innovation, Necessity, Practice.

\begin{abstract}
This paper analyzes the background of the current college management and services, elaborates the inevitability of the innovation of college management and service model from the aspects of higher education reform and the development of information technology, building a harmonious campus, improving the personnel training quality, enhancing the level of management. Next the paper introduces the innovation practice of the mode of management and service in Beijing University of Aeronautics and Astronautics.
\end{abstract}

\section{Introduction}

Report of the Seventeenth Party Congress put forward "to accelerate the reform of the administrative system, building a service-oriented government, Report of the Eighteenth Party Congress put forward" deepening the comprehensive reform in the field of education, and strive to improve the quality of education". Administrative management plays an important function of organization and coordination in the process of universities' development, is one of the most important standards of evaluating the management level and running efficiency of a university. With the arrival of the era of knowledge economy, the development of information technology and the comprehensive reform in the field of education, it's necessary to innovate the mode of university management and services, which is analyzed and studied in this paper. What's more, this paper introduces the innovation practice in the mode of management and service of Beijing University of Aeronautics and Astronautics (hereinafter referred to as BUAA).

\section{The background and necessity of the innovation of university management service mode.}

\section{Background of the innovation of university management service model}

The internal and external environment of university management services have been changing since twenty-first Century. On the side of external environment, "The world today is undergoing tremendous changes and adjustments,..., knowledge innovation has become the core element of national competitiveness ${ }^{1}$." Talents and education are the core and foundation of knowledge innovation. On the side of internal environment, the field of higher education is also undergoing a comprehensive reform. The development of science and technology, new information technology revolution and the rise of knowledge economy are all affecting the development of higher education which is distinctly characterized by popularization, informationization, industrialization, internationalization and large-scale, reform is a necessity to ensure the comprehensive and coordinated development of higher education. The reform of the management service mode is one of the important content of higher education reform and innovation is undoubtedly an important way.

Therefore, management and service modeinnovation is the trend of modern higher education's reform and development. It is the inner driving force to enhance the college management level, to serve talent training, scientific research and social service better, as well as the inevitable requirement in the process of development for a high level university or the world first-class university. 


\section{The necessity of the innovation of university management service mode}

The innovation of the university management service mode is the need to adapt to the higher education reform and the development of information technology. First of all, after more than a decade' rapid development, China's universities have undergoing profound changes in terms of scale, level and quantities, and its service scope continues to expand, the traditional management mode cannot adapt to the current situation. Secondly, with the continuous change of the national demand and the continuous reform of higher education system, China's universities also need to transform accordingly, including the transformation of the university management service mode. Thirdly, the development of information technology caused the innovation and reform of the education structure, education content and the methods of education. As the foundation to ensure a smooth innovation and reform, college management and service mode must make corresponding reform in order to play a better role of organization and coordination.

The innovation of the university management service mode is the need to build a harmonious campus. The construction of a harmonious campus is the basis to ensure the campus stability and order, to enhance the campus creation activity, and to promote the comprehensive and coordinated development of a university. However, the management services need to provide a strong guarantee to achieve the goal of a harmonious campus, to make sure that the sub-systems and elements in a university work in an interdependent, mutual-coordinated, mutual- promoted way. In the current environment, besides rational allocation of university resources, an appropriate reform and innovation need to be undertaken in terms of the rules, regulations and procedures so as to maintain the normal operation, to construct a harmonious campus, and to promote a better development of a university.

The innovation of the university management service mode is the need to improve the quality of personnel training. Talent cultivation is the fundamental task and the core target of colleges and universities, the value of a university is embodied at a great degree by the outstanding talents. Therefore, personnel training is centered and served by all the works of colleges and universities. The administrative departments should put the idea that "management and services are for talents cultivation" into effect, take teachers and students as the center, and "do well in management in the mind of service ${ }^{(2)}$ ". With the profound change of social development and higher education, the new normal of the teachers' and students' needs that faced by the management departments requires them to innovate and reform accordingly in the management service mode to lay a solid foundation for improving the quality of personnel training.

The innovation of the university management service mode is the need to improve the level of management departments themselves. In the trend of deepening reform and opening to the outside world, the arrival of the global knowledge economy and the continuous change of higher education, management departments of a university cannot achieve the goal of serving and coordinating the comprehensive development of the university unless they adjust their position and innovate the management and service mode. At present, the traditional management model is unable to meet the needs of the new development of a university, it's an inevitable trend that the management departments are changed from right institutions into service ones, and it's an inevitable choice to enhance their consciousness of responsibility and service. Only the functions of management and service coexist, the management departments can lead support and serve the development of a university.

\section{The Innovation practice-the service platform for teachers and students in BUAA}

\section{Implementation background and objectives}

In order to further change the functions of management department, to implement the Party's mass line educational practice, to establish service-oriented concept and carry out the year of "innovative service ${ }^{(3),}$, according to the fact that the management departments are located separately, after many times of discussion and opinions collection, BUAA established a comprehensive service platform for teachers and students (refers to as platform hereinafter). The 
platform aimed to provide high quality, efficient and convenient services for teachers and students by integrating effectively the management functions that are mainly for teachers and students, and it includes online virtual hall and offline entity hall which are supported by the massive amounts of information data, this new mode is called the centralized service mode.

\section{Contents of the platform}

Online service platform. The online service platform is divided into scientific research, financial business, human resources, teaching service, assets and equipment, life service and others according to the nature of business; it is based on the iHome community platform with unified login. All kinds of information resources are shared such as examination and approval, the daily supervision, and public services so that the teachers and students can do business, check the answer, review and complaint online.

Offline service hall. The offline service hall integrated effectively the existing types of business by means of informatization. Except the relatively independent service halls that have been built, this hall focuses on the routine work that are massive in amount and are related to the teachers and students directly and can be finished in a while or in regular intervals. According to the views of teachers and students, the school set up a group of experts to examine and determine the specific business types and the involved management department. Based on the intrinsic logic relation of the business, the offline service hall is divided into scientific research businesses, abroad businesses, student employment services, the school seal and other businesses, covering 11 departments and 71 businesses. After the dynamic adjustment based on the actual operation, at present the hall mainly covers 62 businesses such as scientific research businesses, student employment services, network information services, seal businesses, educational administration, staff' businesses, household and other business.

\section{Implement security}

Strengthen organization and leadership. Since the beginning of the proposal the hall has got strong support from the leaders of BUAA, the office which in charge of party affairs and administrative businesses is responsible for the overall construction plan, the network information center is responsible for the overall construction of the online service hall, the administrative office is responsible for the operation of offline service hall, other administrative departments must do a good job of their own according to the division of business.

Strengthen supervision and evaluation. The hall has established business evaluation system, each one who comes for a business can give a comprehensive evaluation on the effect of the business and the behavior of the staff. In addition, the hall plans to establish a perfect inspection mechanism so as to ensure a good supervision and inspection. At the same time, the Expert Committee will evaluate the businesses in the service hall and have a timely adjustment of the post based on the situation of the business development.

\section{Implementation effect}

The hall was in trial operation since December 26, 2013, and has been running officially since January 5, 2014, By the end of November 30, 2014, there have been a total of 108664 businesses dealt in the hall, 466 businesses every working day on average, the efficiency has been improved greatly. In addition, the relevant departments combed through all their businesses on this occasion, one staff can accept all the businesses in the hall now while he was only responsible for a specific job before, thereby saving the human cost. The service platform provides a basis for improving the comprehensive management ability as well as the modernization of management service of BUAA.

\section{Notes}
(1)Report
of
the
Seventeenth
Party
Congress,

http://www.chinapeople.com/peopleele/pqrty/pqrtyinfo.aspx?pid=4044

(2)Guo Dacheng. How to Practice the Management Service Concept with the Core of Talent 
Cultivation. [J] China Higher Education, 2009(24):7-8.

(3)The subject year of BUAA

\section{Acknowledgement}

This article is sponsored by the item Research on development strategy and higher education.(ID: YWF-15-FZGHC-041.

\section{References}

[1] Huang Shengchun,Under the background of the information technology innovation of college administration management, J. Higher Education, 2012(9):161-169.

[2] Ma Yongbin, Wu Jianping, Tu Zhonghua, Zhaowei, Information and Management Invention in Institutions of Higher Educaiton, J. Research on Education Tsinghua University, 2002(2):83-86.

[3] Guo Dacheng, How to Practice the Management Service Concept with the Core of Talent Cultivation, J. China Higher Education, 2009(24):7-8. 